\title{
STUDIES ON THE ACTION OF DIURETICS
}

\section{THE EFFECT OF EUPHYLLIN AND SALYRGAN UPON GLOMERULAR FILTRATION AND TUBULAR REABSORPTION ${ }^{1}$}

\author{
BY HENRY LENZEN SCHMITZ \\ (From the Lasker Foundation for Medical Research and the Department of Medicine, \\ University of Chicago, Chicago)
}

(Received for publication May 3, 1932)

Since the appearance in 1887 of von Schroeder's first publication (1) concerning the action of xanthine diuretics there has been much debate regarding the mechanism by which these substances produce diuresis. Similarly there has been considerable controversy as to the manner in which salyrgan and other organic mercury compounds increase the output of urine.

\section{REVIEW OF LITERATURE}

In the earlier work on xanthine diuresis investigators were chiefly interested in distinguishing between direct action on the renal cells and effects produced through changes in renal circulation. Von Schroeder (1) (2) concluded from his experiments that the effect of caffeine and related substances upon urine output was independent of circulatory changes. Loewi, Fletcher and Henderson (3) held the opposite point of view. They confirmed the observation, first made by Phillips and Bradford (4), that caffeine usually increases the volume of the kidney and considered this as evidence that diuresis was caused by dilatation of the renal blood vessels. Although this observation concerning kidney volume during caffeine diuresis is generally accepted, its significance has been questioned by Gottlieb and Magnus (5) because diuresis sometimes occurs without increase in kidney volume, by Brings and Molitor (6) who concluded that the increase in volume was of too short duration to be significant, and by Cushny (7) who pointed out that increase in kidney volume does not necessarily indicate vasodilatation.

It has been demonstrated by direct measurement that there is usually an increase in renal blood flow following the administration of the xanthine diuretics. However, the evidence seems to indicate that the diuresis is independent of this. Cushny and Lambie (8), E. Schmidt (9), Ozaki (10), and $R$. Schmidt (11) have reported that the acceleration in rate of blood flow is of short duration and that diuresis may begin before the increase occurs and persist after the flow has returned to normal. Richards and Plant (12) demonstrated that caffeine increased the output of the perfused rabbits' kidney when the rate of blood flow was kept constant, and Gremels (13) (14), working with a Starling heart-lung-kidney preparation, obtained diuresis with caffeine, theobromine and theocin when increase in rate of flow was prevented by previously dilating the renal vessels to a maximum. Miwa and Tamura (15) found no increase

1 The major part of this work was reported at the 1931 meeting of The American Society for Clinical Investigation. 
in renal blood flow during caffeine diuresis, and Hartwich (16) observed diuresis in the isolated kidney of the frog perfused with Ringer's solution, without increase in rate of perfusion flow. Dreyer and Verney (17) have presented evidence that the rate of urine flow is independent of the velocity of blood flow.

These observations do not, however, dispose of the possibility that xanthine diuresis is related to changes in the renal vessels. Richards and Schmidt (18) observed, during direct microscopic study of the frog's kidney, that caffeine considerably increased the number of functioning glomeruli and the number of patent capillary loops in individual glomeruli. Richards and his co-workers (19) (20) (21) have also presented evidence that chemical substances may constrict the vas efferens of the frog's glomerulus to a greater degree than the vas afferens. It is conceivable, as Verney and Winton (22) have pointed out, that caffeine increases intraglomerular pressure by dilating the afferent vessels to a greater extent than the efferent vessels, this increase in glomerular capillary pressure not necessarily being accompanied by an increase in rate of blood flow during the whole of diuresis. In support of this hypothesis Verney and Winton have shown, in experiments with the heart-lung-kidney preparation, that increase in perfusion pressure and caffeine produces the same changes in the composition of the urine and that caffeine in large doses regularly produces an increase in rate of blood flow through the kidney.

Von Schroeder, convinced that the increase in urine flow caused by the purine derivatives was independent of circulatory changes, attributed the diuresis to stimulation of the renal cells to greater secretory activity. Gottlieb and Magnus (5), Schmidt (11), Barcroft and Straub (23), Gremels (24), Wohlenberg (25) and others expressed similar views. In support of this theory it has been maintained by Barcroft (23) (26) and Gremels (24) that an increase in oxygen consumption occurs. However, Miwa and Tamura (15) and Hayman and Schmidt (27) found no evidence of increased metabolism and Masuda (28) observed that caffeine action persisted in the presence of potassium cyanide. Wohlenberg (25) stated that the action of weak caffeine and theophyllin solutions on the perfused frog's kidney could be prevented by asphyxiation or narcotization of the metabolic processes occurring in the glomeruli. Since larger doses of the diuretics were effective in spite of such asphyxiation and narcotization he was forced to admit the possibility of other factors such as increased permeability of the glomerular membrane.

Sobierański (29) reported that indigotate stained the tubular epithelium less than normally during caffeine diuresis, and maintained that the purine derivatives acted by inhibiting reabsorption in the tubules. This observation can just as readily be explained on the basis that a more rapid flow of fluid down the tubules afforded less opportunity for diffusion of the dye into the tubule cells. Tashiro and Abe (30) repeated Sobierański's experiments and obtained similar results, but Teploff (31) found no evidence that theocin had any influence upon the extent to which the cells of the renal tubules were stained by carmine.

Cushny (7) agreed that the purine derivatives had a direct action on the renal cells but suggested on the basis of his "Modern Theory" of urine secretion that the permeability of the capsule was increased and the resistance to filtration thus reduced. Brühl (32) conducted experiments with collodion membranes, the pores of which were filled with albumin to simulate the capsule. He reported a reversible increase in permeability in the presence of caffeine and considered this due to a change in the dispersion of the protein molecules in the pores.

In recent years many investigators have attributed the action of the 
xanthine diuretics to extra-renal factors. Veil and Spiro (33) and Ellinger, Heymann and Klein (34) (35) reported that caffeine increased the capacity of blood serum for ultrafiltration, and proposed that the purines reduced the affinity of the proteins for water. Faludi (36) was unable to confirm this observation and Meyer (37) recently reported that euphyllin increased the water binding power of the blood.

Asher and his pupils maintain that the xanthine diuretics act by increasing the permeability of the tissues, the response on the part of the kidneys being secondary to an increase of chloride and other electrolytes in the blood stream. This theory receives its principal support from the observation made by Curtis (38) (39) (40) (41) that the diuretic action of euphyllin is decreased by the simultaneous intraperitoneal injection of isotonic or hypotonic sucrose solution, and is blocked almost completely by a similar injection of distilled water, these injections preventing the slight increase in plasma sodium chloride concentration which was observed in control experiments and which was considered the prime factor in stimulating the kidney to greater activity. Hartwich (42) found, on the other hand, that the intraperitoneal injection of hypertonic salt solution, which presumably withdrew water from the blood, did not prevent euphyllin from producing diuresis. Riesen (43) reported that euphyllin increased the electrolyte concentration of an artificial fluid perfused through the intestines of the frog. The observations made by Nakao (44) (45) and Raulston (46) are of interest but do not lend much support to the Asher theory.

It is difficult to understand how a change in tissue permeability can increase the electrolyte concentration of the plasma. It would be more logical to assume that a shift of water and salt from the tissues to the plasma occurred as the result of an increase in hydrogen ion concentration. The fact that the xanthine diuretics produce diuresis when the kidneys are isolated from the other tissues (11) (13) (16) (22) makes such an assumption unnecessary. Büchler (47) conceded that the "specific diuretics" had a direct renal action since diuresis occurred in the isolated kidney of the frog, but concluded that this renal action played an insignificant rôle because the amount of diuretic necessary to produce the effect was large and the resulting increase in urine output was small.

Meyer's report (37) that the colloid osmotic pressure of the blood is increased after the intravenous injection of euphyllin has been referred to above. $\mathrm{He}$ also expressed the opinion that euphyllin had both a renal and an extrarenal action. Molitor and Pick (48) concluded from their experiments that the purines acted through the medium of a center in the hypothalamus which regulated the water exchange.

In the case of the organic mercury compounds most investigators have directed their attention to changes in the chemistry of the blood and urine during diuresis in an effort to prove or disprove the extra-renal action of these substances. Saxl and Heilig (49) were the first to call attention to the fact that novasurol causes a relative as well as an absolute increase of sodium chloride in the urine. This observation has been generally confirmed. The concentration of urea, on the other hand, decreases and the absolute amount shows no significant change (Saxl and Heilig (49), Crawford and McIntosh (50), Keith and Whelan (51), Melville and Stehle (52)). Keith and Whelan (51) also reported that there was no appreciable change in the amount of calcium, phosphorus or sulphate excreted in the urine while potassium and magnesium showed a slight increase. This marked increase in excretion of sodium chloride without significant change in the other constituents of the urine has led many investigators to believe that the primary action of novasurol is an extra-renal mobilization of salt and water. Sometimes the concentration of chloride in 
the urine rises to a value above that in the plasma. Möller (53) concluded that this could only be explained by a direct action on the kidneys although he agreed, on the basis of other findings, that mercurial diuretics also had an extra-renal effect.

Studies of the blood electrolytes indicate that no significant changes occur following the administration of the mercurial diuretics. Nonnenbruch (54) and Möller (53) found no change in the concentration of sodium chloride while Saxl and Heilig (55) reported an initial increase followed quickly by a fall. Crawford and McIntosh (50) observed a slight decrease in the concentration of sodium chloride but found no change in the urea. Keith and Whelan (51) stated that changes in the blood were inconstant and never marked. Noguchi (56) reported that the concentration of potassium in the serum was considerably increased. He found a similar increase in potassium during the ingestion of large amounts of water and considered this significant.

Many investigators have studied the concentration of protein in the plasma as a measure of the presence or absence of hydremia. The reports are conflicting and one gets the impression on reviewing the work that too much significance has of ten been attached to slight changes. Saxl and Heilig (49) in their original publication stated that they often found a decrease in the concentration of protein in the plasma subsequent to the injection of novasurol but that this did not occur regularly. Later they reported experiments on normal dogs in which they found an early decrease in concentration with a subsequent rise (55). Bohn (57) (58) also reported a prompt fall in protein concentration after the administration of novasurol. This fall lasted only a short time and was followed by an increase in concentration which he considered due to secondary factors. Bohn and Saxl and Heilig concluded that the action of novasurol was of an extra-renal nature. The findings of Crawford and McIntosh (50) were similar to those quoted above but were interpreted somewhat differently. These authors felt that the drug acted not only on the extra-renal tissues but also on the kidneys, the action on the kidneys being the important one during the greater part of the diuresis. Serby (59) came to the same conclusion largely on the basis of plasma protein determinations in one case. Mühling (60), on the other hand, reported a primary increase and a later fall in concentration and concluded that the primary action was on the kidneys, which responded with an increase in excretion of water and sodium chloride with the result that salt and water were secondarily drawn from the tissues into the blood. Nonnenbruch (54) observed an increase in plasma protein concentration. Since the erythrocyte count was unchanged he considered this increase absolute and not due to loss of water from the blood. Bleyer (61) could demonstrate no constant change. A definite fall in concentration occurred in only one of his nine experiments. In six of the remaining there were slight increases or decreases not exceeding the limits of error of the method employed.

During a certain stage of uranium nephritis Saxl and Heilig (55) observed a marked fall in the plasma proteins, following the injection of novasurol, which persisted for hours. This they considered evidence of extra-renal action, the mobilized salt and water remaining in the blood because the damaged kidneys were unable to excrete them. Bohn (57) obtained similar results in experiments on nephrectomized rabbits and Möller (53) reported that salyrgan caused a fall in hemoglobin and an increase in serum chloride when administered to animals after removal of the kidneys. The normal water metabolism is so disturbed in experiments of this nature that one wonders whether it is justifiable to draw any conclusions. 
Feher (62) determined the blood volume by means of the trypan red method and reported a marked increase three hours after the administration of salyrgan. Since a considerable interval necessarily intervened in each instance between the control determination and the determination after salyrgan other factors may have contributed to the changes observed.

Tezner (63) studied the absorption time of subcutaneously injected normal saline solution. He found that the solution was absorbed with somewhat greater rapidity after the administration of novasurol, and interpreted this as evidence that salt and water were being mobilized for excretion. This phenomenon can also be accounted for by a primary renal action.

Recht (64) and Brunn (65) also supported the theory that the mercurial diuretics act primarily on the extra-renal tissues. Meyer (66) reported that the colloid osmotic pressure of the blood usually decreased after the injection of salyrgan and then with the onset of diuresis rose again above the control value. In some instances, an immediate increase was observed. He was of the opinion that salyrgan decreased the water binding power of the extra-renal tissues but believed that it also had a direct, but less significant, renal action. Fodor (67) concluded that novasurol acted neither directly on the kidneys nor on the tissues, but on a hypothetical center in the medulla which regulated the water and chloride metabolism.

The evidence presented by Gremels (14), Schmidt (11) and Govaerts (68) indicates that the mercurial diuretics act directly on the kidneys. Gremels demonstrated that good diuresis could be obtained from salyrgan and novasurol in the Starling heart-lung-kidney preparation, and Schmidt observed an increase in urine flow from the kidneys of frogs perfused with colloid-free solutions. Govaerts attacked the problem in a very ingenious manner by transplanting kidneys from one animal into the neck of another. When the kidneys from an animal previously given an intravenous dose of novasurol were connected with the circulation of an animal which had received no diuretic, the transplanted kidneys produced an increased amount of urine while the animal's own kidneys continued to excrete urine at a normal rate. When the converse experiment was tried, the transplanted kidneys in the neck put out a normal amount of urine while the animal's own kidneys showed a diuresis.

No correlation between novasurol or salyrgan diuresis and blood flow through the kidneys was found by Gremels, Schloss (69) or Schmidt. An increase in oxygen consumption was reported by Gremels, who concluded that these substances acted directly on the kidneys by stimulating secretion. Kulcke (70) expressed the view that novasurol acted on the tubule cells, small amounts stimulating the secretory function, larger amounts injuring and destroying the cells, as in bichloride poisoning.

From this review of the literature it is obvious that further evidence regarding the mechanisms by which these diuretics increase the output of urine is desirable.

In 1926 Rehberg (71) proposed a method for measuring glomerular filtration and tubular reabsorption. This method is based upon the premises that urine is formed in mammals by a process of filtration and reabsorption and that creatinine is a non-threshold substance and hence is not reabsorbed in the tubules. These premises are well substantiated by the work of Richards, Rehberg, Ekehorn (76) and others to whose publications the reader is referred. From this starting point Rehberg 
reasoned that the concentration of creatinine in the urine times the urine volume must equal the concentration of creatinine in the glomerular filtrate times the volume of the glomerular filtrate. Since glomerular fluid is a protein-free filtrate of the plasma, the concentration of creatinine in the plasma may be substituted for the concentration of creatinine in the glomerular filtrate. By parallel determinations of creatinine in the plasma and in the urine it is thus possible to calculate the amount of glomerular fluid formed per unit of time. The amount of reabsorption occurring in the tubules is then determined by subtracting the urine volume from the amount of glomerular filtrate.

In the experiments reported below, this method of Rehberg has been employed to investigate the influence of euphyllin and salyrgan upon glomerular filtration and tubular reabsorption. Chrometzka and Unger (72) have recently published the results of similar experiments.

\section{PROCEDURE}

The experiments were performed upon eight female dogs weighing between ten and thirteen kilos. Food was withheld from the animals for fifteen hours preceding the experiment. Three hours before the beginning of the experiment proper 3 grams of creatinine in $50 \mathrm{cc}$. of water were given by stomach tube. This sufficed to raise the initial concentration of creatinine in the plasma to values ranging from 5 to 10 or more $\mathrm{mgm}$. per $100 \mathrm{cc}$. and thus made the determinations more accurate. During the course of the experiment the amount of creatinine in the plasma steadily decreased. Hence a fairly accurate average concentration for each period of observation could be obtained. The animals were allowed no water for at least one hour preceding the experiment. At the end of this period the absorption of any water previously present in the alimentary tract had, as a rule, produced its maximum effect upon the urine output. The fluid intake preceding this period of abstinence was varied considerably in order to vary the initial urine volume. In some instances water was withheld entirely except for the small amount given along with the creatinine. In other experiments water was permitted ad libitum. When large initial urine volumes were desired, water was given by stomach tube in amounts as high as $200 \mathrm{cc}$. per hour.

During the experiment proper urine collections were made for successive periods before and after the administration of the diuretic to be studied. These collections were made directly into accurately graduated cylinders by means of a stiff rubber catheter inserted into the bladder through the urethra. The catheter was left in place throughout the experiment. Toward the end of each period it was moved about to assure as complete emptying of the bladder as possible.

In some experiments blood samples were obtained at the middle of each period of urine collection. Usually, however, fewer blood specimens 
were taken and the concentration of creatinine corresponding to the middle of each period was then obtained by graphing the known values. The creatinine determinations were made by the method of Folin (73). Both euphyllin and salyrgan were given intravenously. The saline injections were made by the gravity method.

As a rule, two or more control periods of ten minutes each were obtained before the diuretic was administered. When the initial urine volume was quite small a single long control period was used. When the urine volume showed a tendency to increase during the control periods the administration of the diuretic was postponed until the urine output began to decrease. In addition to these control periods preceding the administration of diuretics several control experiments were performed.

The results of the experiments are presented in the accompanying tables and graphs. For purposes of comparison the urine volumes and rates of glomerular filtration are expressed in terms of cubic centimeters per minute. The amount of fluid reabsorbed in the tubules per minute is expressed as the per cent of the corresponding volume of filtrate.

\section{Controls}

The variations in glomerular filtration and in tubular reabsorption which occurred during successive periods of observation under the conditions of the experiment are shown in Table 1. The changes in filtration

TABLE 1

Spontaneous variations in glomerular filtration and tubular reabsorption

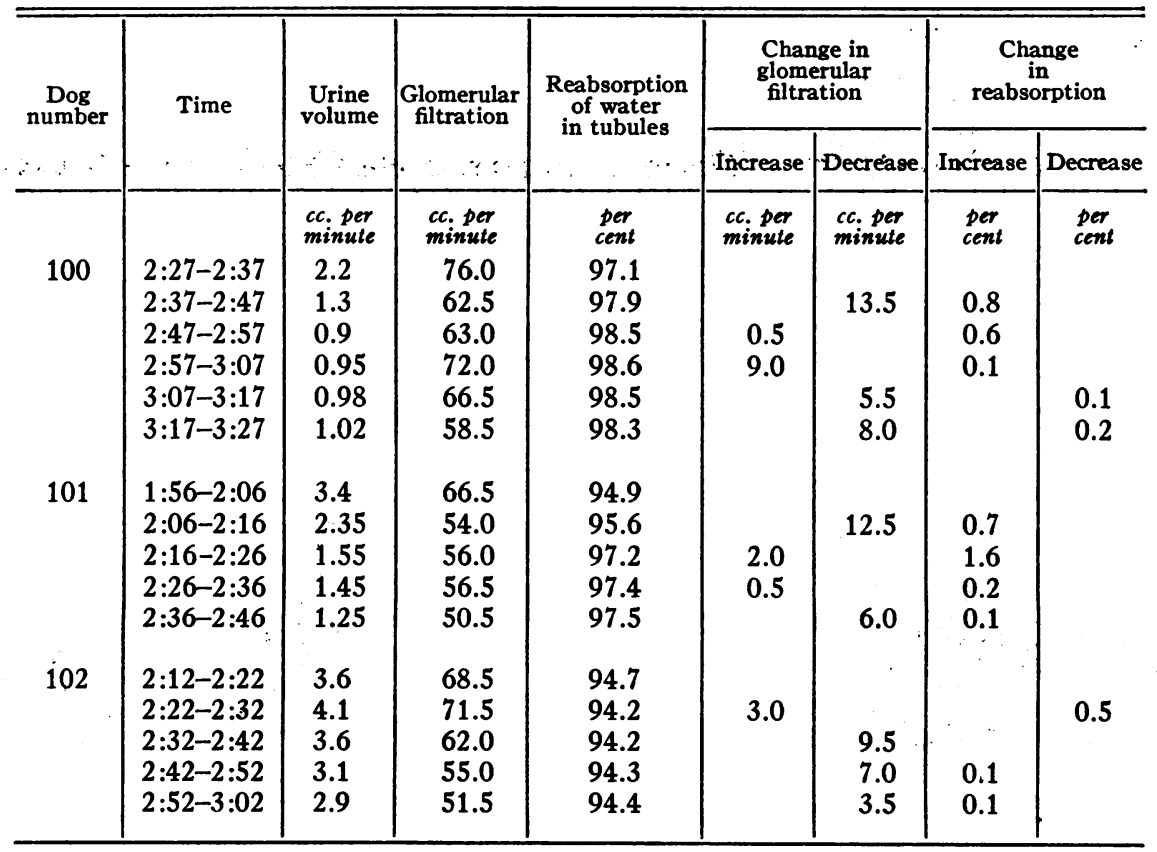


TABLE 1 (continued)

\begin{tabular}{|c|c|c|c|c|c|c|c|c|}
\hline \multirow{2}{*}{$\begin{array}{c}\text { Dog } \\
\text { number }\end{array}$} & \multirow{2}{*}{ Time } & \multirow{2}{*}{$\begin{array}{c}\text { Urine } \\
\text { volume }\end{array}$} & \multirow{2}{*}{$\begin{array}{l}\text { Glomerular } \\
\text { filtration }\end{array}$} & \multirow{2}{*}{$\begin{array}{c}\text { Reabsorption } \\
\text { of water } \\
\text { in tubules }\end{array}$} & \multicolumn{2}{|c|}{$\begin{array}{l}\text { Change in } \\
\text { glomerular } \\
\text { filtration }\end{array}$} & \multicolumn{2}{|c|}{$\begin{array}{l}\text { Change } \\
\text { in } \\
\text { reabsorption }\end{array}$} \\
\hline & & & & & Increase & Decrease & Increase & Decrease \\
\hline \multirow{4}{*}{102} & & $\begin{array}{l}c c \text {. per } \\
\text { minute }\end{array}$ & $\begin{array}{l}\text { cc. per } \\
\text { minute }\end{array}$ & $\underset{\text { cent }}{\text { per }}$ & $\begin{array}{l}\text { cc. per } \\
\text { minute }\end{array}$ & $\begin{array}{l}c c . \text { per } \\
\text { minute }\end{array}$ & $\begin{array}{c}\text { per } \\
\text { cent }\end{array}$ & $\begin{array}{c}\text { per } \\
\text { cent }\end{array}$ \\
\hline & $2: 08-2: 18$ & 1.8 & 59.0 & 96.9 & & & & \\
\hline & $2: 18-2: 28$ & 1.35 & 53.0 & 97.4 & & 6.0 & 0.5 & \\
\hline & $2: 28-2: 38$ & 1.2 & 50.5 & 97.6 & & 2.5 & 0.2 & \\
\hline \multirow[t]{4}{*}{103} & $2: 06-2: 16$ & 4.7 & 142.0 & 96.7 & & & & \\
\hline & $2: 16-2: 26$ & 5.1 & 137.0 & 96.3 & & 5.0 & & 0.4 \\
\hline & $2: 26-2: 36$ & 4.1 & 129.5 & 96.8 & & 7.5 & 0.5 & \\
\hline & $2: 36-2: 46$ & 2.45 & 121.5 & 97.9 & & 8.0 & 1.1 & \\
\hline \multirow[t]{3}{*}{103} & $2: 14-2: 25$ & 1.36 & 101.0 & 98.7 & & & & \\
\hline & $2: 25-2: 35$ & 0.9 & 75.0 & 98.8 & & 26.0 & 0.1 & \\
\hline & $2: 35-2: 45$ & 0.35 & 56.0 & 99.4 & & 19.0 & 0.6 & \\
\hline \multirow[t]{4}{*}{104} & $1: 06-1: 16$ & 1.55 & 81.5 & 98.1 & & & & \\
\hline & $1: 17-1: 27$ & 1.42 & 64.5 & 97.8 & & 17.0 & & 0.3 \\
\hline & $1: 27-1: 37$ & 1.35 & 64.0 & 97.9 & & 0.5 & 0.1 & \\
\hline & $1: 37-1: 47$ & 1.0 & 62.5 & 98.4 & & 1.5 & 0.5 & \\
\hline \multirow[t]{3}{*}{104} & $2: 05-2: 25$ & 0.18 & 91.0 & 99.8 & & & & \\
\hline & $2: 25-2: 45$ & 0.17 & 81.0 & 99.8 & & 10.0 & & \\
\hline & $2: 45-3: 05$ & 0.16 & 85.0 & 99.8 & 4.0 & & & \\
\hline \multirow[t]{4}{*}{105} & $2: 15-2: 25$ & 2.1 & 56.5 & 96.3 & & & & \\
\hline & $2: 25-2: 35$ & 2.25 & 58.5 & 96.1 & 2.0 & & & 0.2 \\
\hline & $2: 35-2: 45$ & 1.8 & 57.0 & 96.8 & & 1.5 & 0.7 & \\
\hline & $2: 45-2: 55$ & 1.64 & 58.0 & 97.2 & 1.0 & & 0.4 & \\
\hline \multirow[t]{3}{*}{105} & $2: 25-2: 35$ & 3.3 & 96.0 & 96.5 & & & & \\
\hline & $2: 35-2: 45$ & 3.45 & 89.5 & 96.1 & & 6.5 & & 0.4 \\
\hline & $2: 45-2: 55$ & 3.55 & 96.5 & 96.3 & 7.0 & & 0.2 & \\
\hline \multirow[t]{4}{*}{106} & $1: 47-2: 02$ & 0.5 & 35.0 & 98.6 & & & & \\
\hline & $2: 02-2: 17$ & 0.6 & 22.0 & 97.3 & & 13.0 & & 1.3 \\
\hline & $2: 17-2: 37$ & 0.25 & 20.0 & 98.7 & & 2.0 & 1.4 & \\
\hline & $2: 37-2: 58$ & 0.12 & 34.0 & 99.6 & 14.0 & & 0.9 & \\
\hline \multirow[t]{4}{*}{106} & $3: 32-3: 42$ & 3.35 & 80.0 & 95.8 & & & & \\
\hline & $3: 44-3: 55$ & 3.1 & 75.0 & 95.8 & & 5.0 & & \\
\hline & $3: 55-4: 05$ & 2.75 & 71.0 & 96.1 & & 4.0 & 0.3 & \\
\hline & $4: 05-4: 15$ & 2.4 & 69.5 & 96.5 & & 1.5 & 0.4 & \\
\hline \multirow[t]{4}{*}{106} & $2: 03-2: 13$ & 2.3 & 69.5 & 96.7 & & & & \\
\hline & $2: 13-2: 23$ & 2.0 & 66.0 & 96.9 & & 3.5 & 0.2 & \\
\hline & $2: 23-2: 33$ & 1.85 & 55.0 & 96.6 & & 11.0 & & 0.3 \\
\hline & $2: 33-2: 43$ & 1.07 & 54.0 & 98.0 & & 1.0 & 1.4 & \\
\hline \multirow[t]{4}{*}{107} & $2: 00-2: 15$ & 1.73 & 44.0 & 96.1 & \multirow{4}{*}{5.5} & & \multirow{4}{*}{1.8} & \\
\hline & $2: 15-2: 30$ & 1.93 & 41.0 & 95.3 & & 3.0 & & 0.8 \\
\hline & $2: 30-2: 45$ & 1.33 & 46.5 & 97.1 & & & & \\
\hline & $2: 45-3: 00$ & 1.33 & 43.0 & 96.9 & & 3.5 & & 0.2 \\
\hline
\end{tabular}


represent not only actual increases or decreases in rate of formation but also the variations resulting from experimental errors such as those occurring in the creatinine determinations. Of primary interest are increases in filtration and decreases in reabsorption, the two factors which tend to augment urine output. Increases in filtration occurred infrequently and seldom were significant. The maximum observed was 14 cc. per minute. Decreases in the percentage of reabsorption in the tubules were also uncommon. The largest decrease was 1.3. In the majority of instances, decreases in filtration and increases in percentage reabsorption occurred, both of these factors tending to diminish the urine volume.

\section{Euphyllin experiments}

The experiments with euphyllin may be divided into two groups, those in which diuresis was obtained, and those in which no increase in urine output occurred. The results of the former group are presented in Table 2 and Figure 1.

Euphyllin diuresis was characteristically associated with an increase in the calculated rate of glomerular filtration. In a few experiments the maximum rate of filtration immediately preceded the maximum urine volume. In experiments 57 and 58 diuresis persisted after the rate of filtration had returned to normal. Changes in reabsorption were variable. In experiments 1,4 and 14 the percentage reabsorption was definitely increased. In four other experiments $(34,50,63$ and 64$)$ there was no significant change during the course of the diuresis. In only three instances were there decreases in reabsorption which definitely exceeded the maximum observed in the controls. However, the occurrence of decreases was more frequent than in the control experiments and in a number of instances decreased reabsorption contributed considerably to the increase in urine output.

The urine output after the intravenous injection of $2 \mathrm{cc}$. of euphyllin only twice exceeded $2 \mathrm{cc}$. per minute. As a rule diuresis began within five minutes after the administration of the drug.

Practically all of the failures to obtain diuresis with euphyllin occurred in experiments in which the urine volume to begin with was $1 \mathrm{cc}$. per minute or greater. In fifteen of seventeen experiments in which the control urine volumes were below $1 \mathrm{cc}$. per minute the injection of euphyllin was followed by diuresis. In four experiments with initial urine volumes ranging between $1 \mathrm{cc}$. and $1.4 \mathrm{cc}$. per minute, the response to euphyllin was variable. In six experiments with control urine volumes greater than $1.5 \mathrm{cc}$. per minute, there was a decrease in urine volume following the injection of euphyllin. In the latter experiments the rate of filtration increased within ten to twenty minutes after the administration of the drug, but this rise in filtration was more than counteracted by a considerable increase in the percentage of reabsorption in the tubules. 


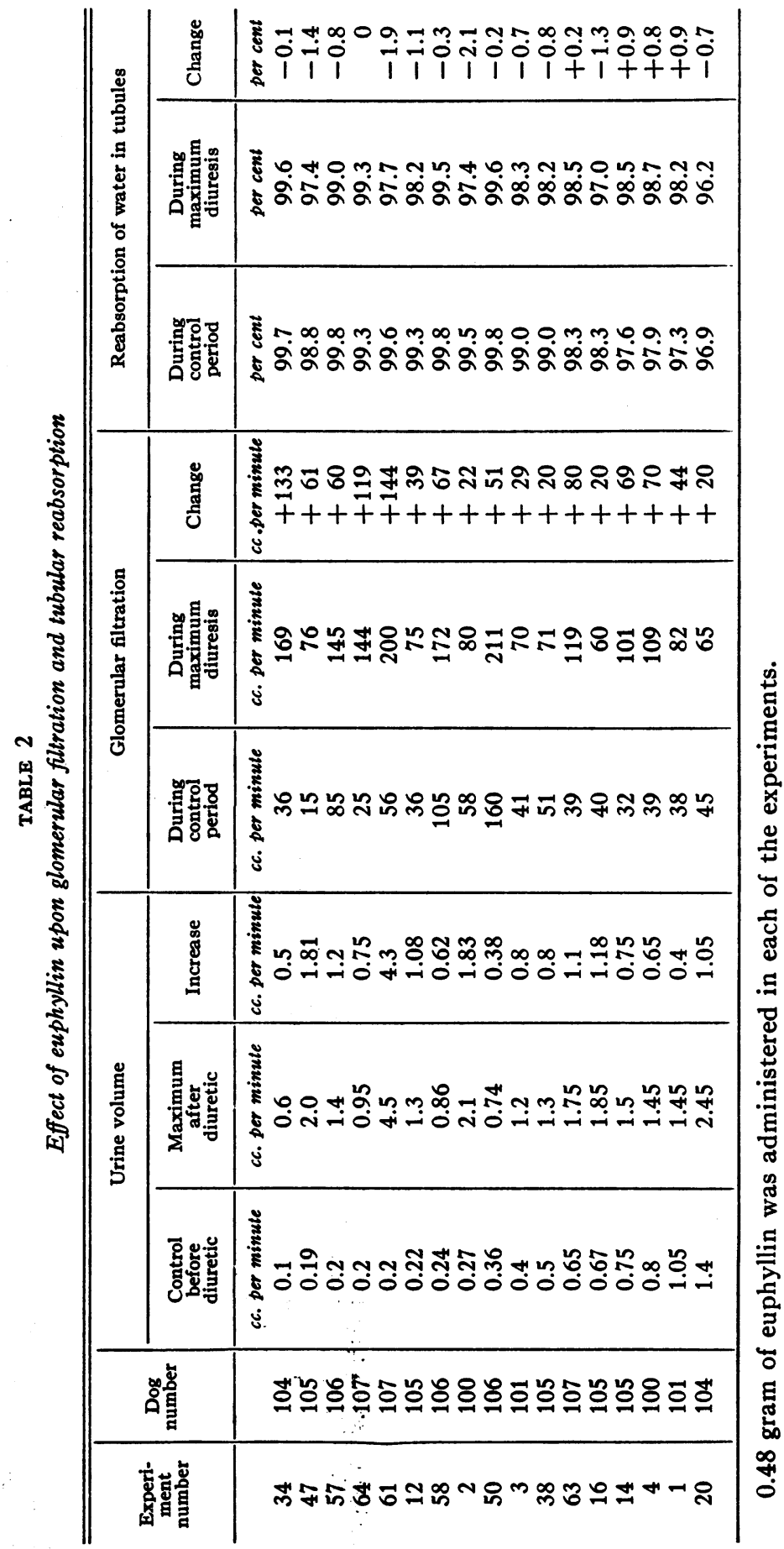




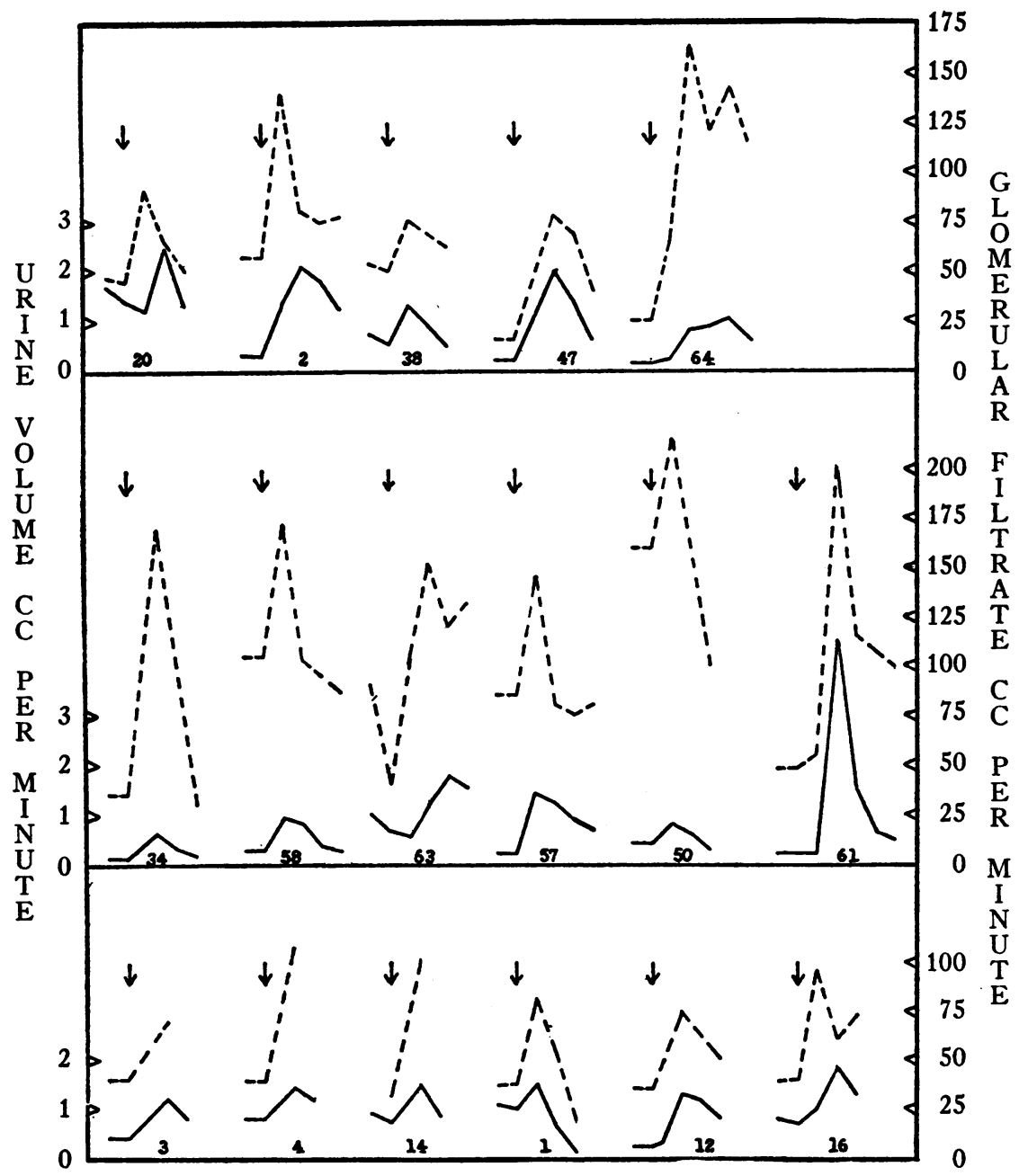

Fig. 1. Rate of Glomerular Filtration During Euphyllin Diuresis

The arrows indicate when euphyllin was injected. Solid line $=$ urine volume. Broken line $=$ glomerular filtrate.

This is illustrated by Figure 3 in which one of the experiments is presented graphically.

\section{Salyrgan experiments}

The results obtained with salyrgan (see Table 3 and Figure 2) are in sharp contrast to those given by euphyllin. The percentage reabsorption in the tubules was significantly decreased in all but one instance, the decreases ranging from 1.6 to 4.6. A definite increase in filtration, on the other hand, occurred in only four of the fourteen experiments and in only one instance (experiment 6) played any significant rôle in the production of diuresis. 
Salyrgan was effective even when the control urine volume was as high as $3.5 \mathrm{cc}$. per minute. Rates of urine excretion as high as 5, 6.8 and $9.4 \mathrm{cc}$. per minute were obtained. The response to salyrgan is less rapid than that to euphyllin. In the majority of experiments diuresis began 15 to 20 minutes after the intravenous administration of the drug. There were only two instances in which salyrgan failed to cause diuresis.

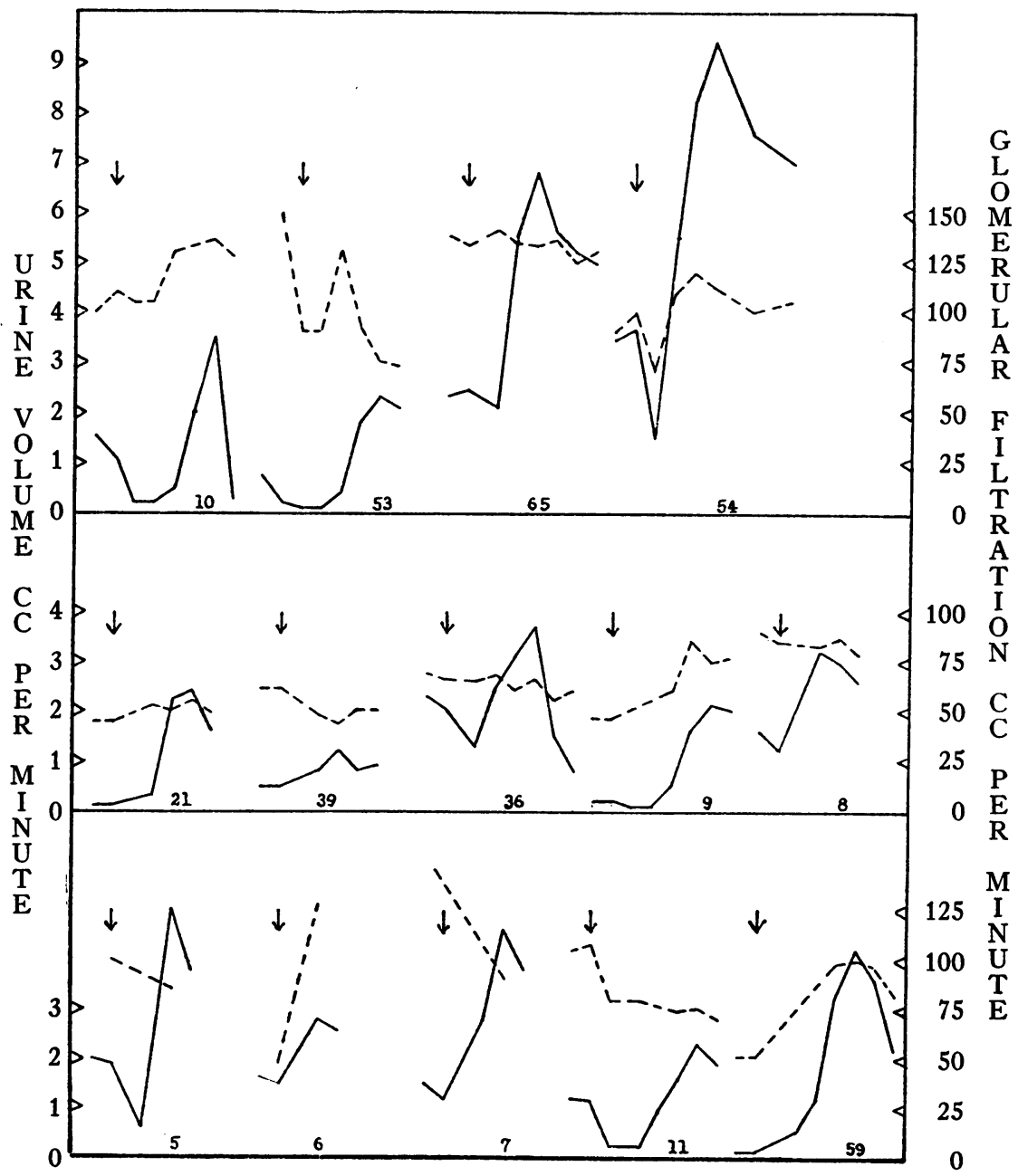

Fig. 2. Rate of Glomerular Filtration During Salyrgan Diuresis

The arrows indicate when salyrgan was injected. Solid line $=$ urine volume. Broken line $=$ glomerular filtrate.

\section{Intravenous normal saline solution}

Because many investigators have maintained both in the case of euphyllin and in the case of salyrgan that diuresis is the result of a primary 
extra-renal mobilization of salt and water the effect of normal saline solution given intravenously was studied for purposes of comparison. The amount of saline and the rate of injection were varied considerably. See Table 4.

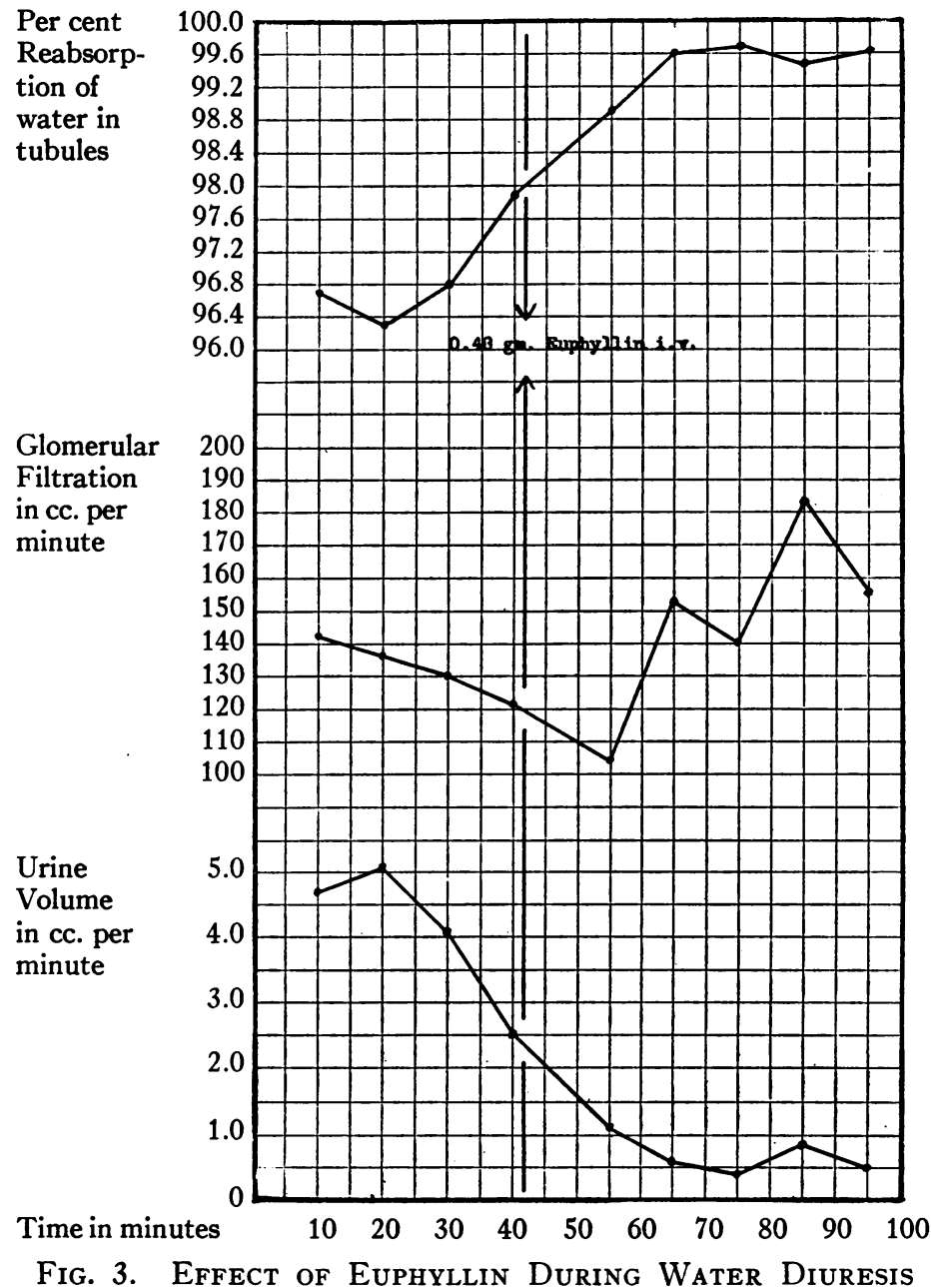

The almost constant increase in rate of glomerular filtration following the injection of saline was outstanding in these experiments. The effect upon reabsorption varied with the amount and the rate of injection of saline. With the smaller amounts decreases in reabsorption were infrequent and seldom significant. When saline was injected continuously at fairly rapid rates, larger decreases in percentage reabsorption occurred. In the latter experiments the increases in filtration always appeared first. As the injection was continued the rate of filtration 


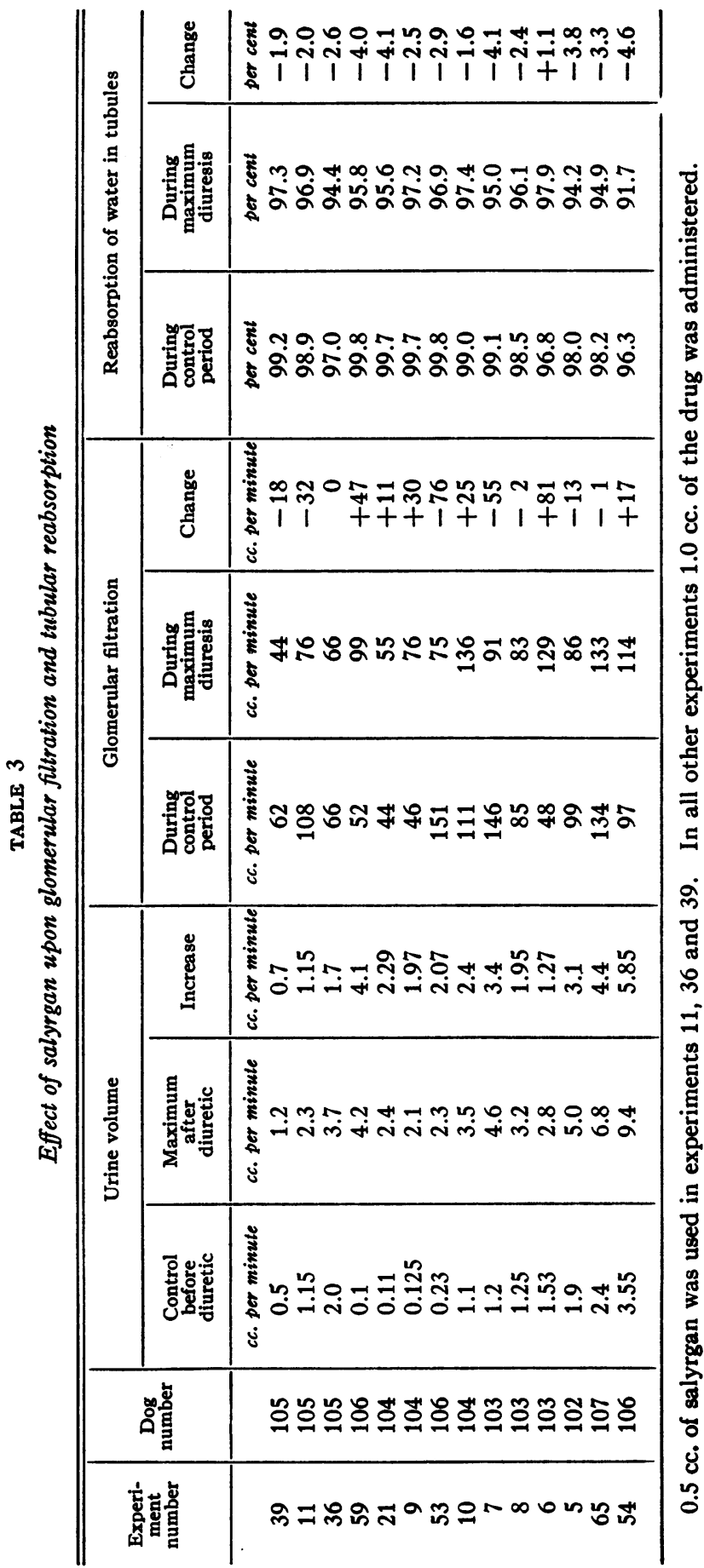




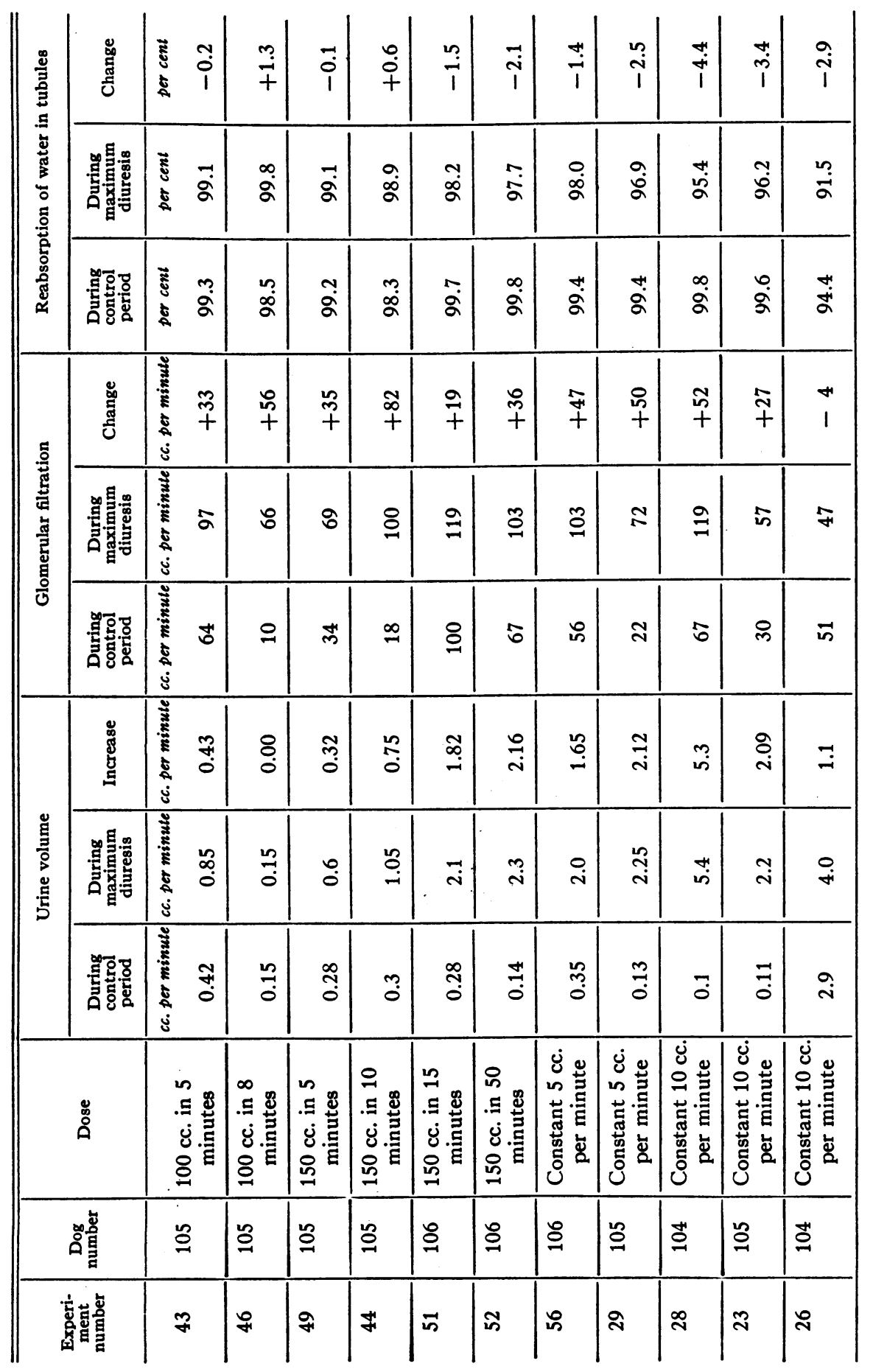


tended to subside while reabsorption decreased. In experiment 26 the rate of filtration, after an initial rise, dropped below the control period level.

\section{COMMENT}

In the experiments with salyrgan, diuresis was characteristically associated with a decrease in tubular reabsorption. Chrometzka and Unger (72) made the same observation. The fact that there is no resemblance between salyrgan and intravenous normal saline solution, so far as effect upon filtration is concerned, is opposed to the view that the response of the kidneys to this mercurial diuretic is secondary to an extra-renal mobilization of salt and water. The observations of Gremels and Govaerts, referred to above, also indicate a direct action on the kidneys. Since larger doses of mercury injure and destroy the epithelium of the renal tubules, it seems logical to assume that this decrease in tubular reabsorption is due to a depressant action upon the tubule cells.

Chrometzka and Unger performed three experiments with diuretin and found no change in the rate of glomerular filtration. In the experiments reported in this paper, however, an increase in rate of glomerular filtration was characteristic of euphyllin diuresis. This finding is consistent with the direct observation of Richards and Schmidt that caffeine increases the number of functioning glomeruli and the number of functioning capillary loops in individual glomeruli. It is also in harmony with Bieter's observation (74) that caffeine and theophyllin do not produce diuresis in fish with aglomerular kidneys.

Since the intravenous injection of normal saline solution also increases the rate of glomerular filtration it is impossible to conclude from these experiments alone whether xanthine diuretics act primarily upon the tissues or upon the renal vessels. The fact that these diuretics are effective in increasing the urine output of the isolated kidney is definitely opposed to the former view. The principal objection to the latter theory has been the lack of correlation between xanthine diuresis and rate of blood flow through the kidney. This objection loses its significance if we assume, as Verney and Winton (22) have proposed in the case of caffeine, that the xanthine diuretics may, under suitable circumstances, dilate the vas afferens to a greater extent than the vas efferens and thus increase the glomerular capillary pressure, the glomerular capillary surface and the rate of glomerular filtration without necessarily increasing the rate of blood flow through the kidney.

Changes in reabsorption following the injection of euphyllin are inconstant. The moderate decreases occurring in many experiments may well be related to increases in the number of patent capillaries in individual glomeruli, larger amounts of fluid flowing down the corresponding tubules more rapidly and lessening the chances for reabsorption.

The diuretic response to salyrgan is considerably greater than that to 
euphyllin. This difference is related to the relative effect of increases in filtration and decreases in reabsorption upon urine volume. Even large increases in filtration can not per se produce large urine volumes whereas relatively small decreases in reabsorption can cause considerable diuresis.

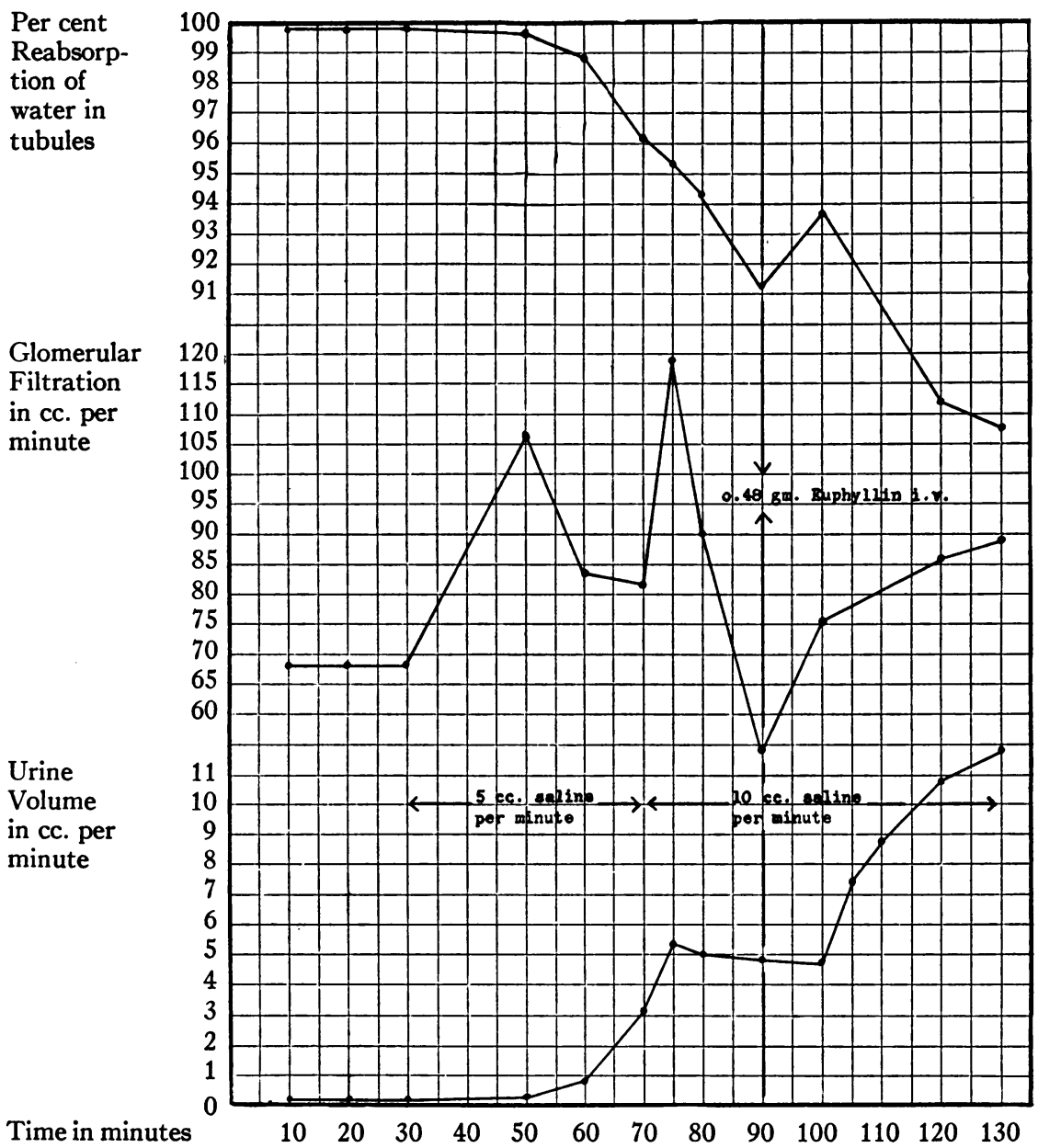

Fig. 4. Effect of Euphyllin During Continuous Intravenous Injection of Normal Saline Solution

Fremont-Smith and his associates (75) found that water diuresis in man was not associated with an appreciable increase in the amount of glomerular filtration. Chrometzka and Unger (72) have made the same observation. In the experiments herein reported, the rates of filtration associated with high control urine volumes, produced by forcing large amounts of water, were moderately higher than the rates of filtration associated with low control urine volumes. The average rate of filtration 
during 38 periods with urine volumes below $1 \mathrm{cc}$. per minute was $54 \mathrm{cc}$. per minute, while the average rate for 10 periods with urine volumes between 3 and $4 \mathrm{cc}$. was $78 \mathrm{cc}$. per minute.

The amount of reabsorption, on the other hand, is considerably reduced during water diuresis. As the diuresis subsides the percentage reabsorption mounts rapidly. This rise in percentage reabsorption would seem to be the significant factor in the failure of euphyllin to increase urine volume under these conditions (see Figure 2). Filtration is increased, but the rising percentage of reabsorption in the tubules more than counteracts the increase in rate of filtration. Presumably if water were administered at a constant rate so as to maintain the percentage of reabsorption at a level, euphyllin would be capable of increasing

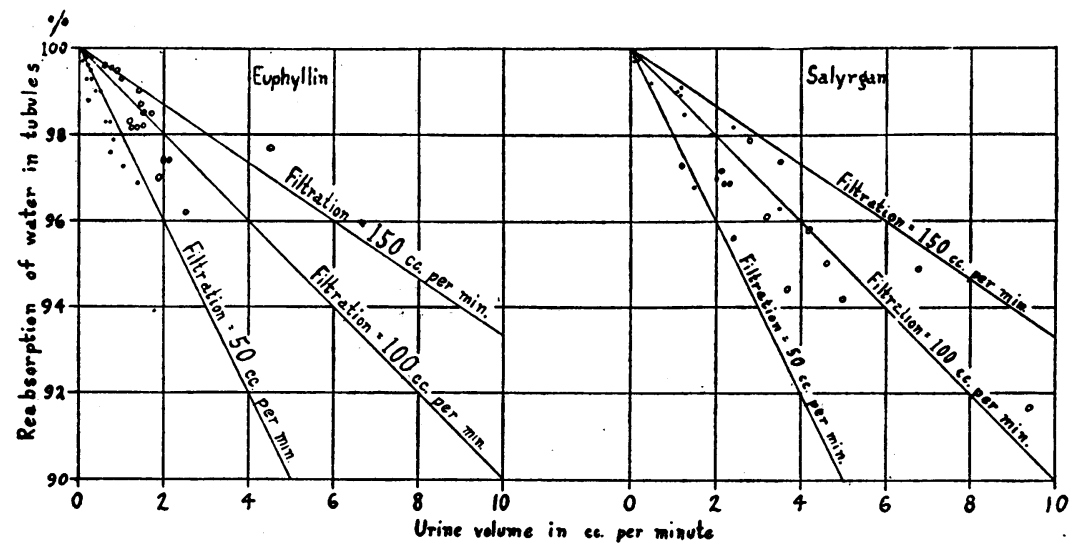

Fig. 5. Graphic Comparison of the Effect of Euphyllin and Salyrgan upon Glomerular Filtration and Tubular Reabsorption

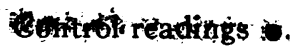

After diuretfc 0 .

the urine volume still further. Euphyllin is effective when the urine output is high as a result of the continuous injection of normal saline solution (Figure 4). It is in fact more effective than usual under these circumstances, because the low percentage of reabsorption in the tubules makes the resulting increase in filtration more significant. Similar results were obtained in two other experiments of this type.

These experiments are of interest to the clinician because they may lead to a better understanding of the clinical results obtained with these drugs. Clinically it has been found that the xanthine diuretics are chiefly of value in hastening the elimination of cardiac edema after digitalis and bed rest have improved the circulation. With improvement in circulation in cardiac failure salt and water previously stored in the tissue spaces are brought to the kidneys for excretion. Under these conditions, as we have seen experimentally, the increase in filtration produced by the purine 
derivatives is more effective than usual because reabsorption is taking place to a lesser degree than normal. In other types of edema (hepatic and renal) the xanthine diuretics are of little help. Increase in filtration, especially when only of a transient nature, is by itself of little value in augmenting the urine output.

The mercurial diuretics, on the other hand, are effective in all three of the above mentioned types of edema. The effectiveness of salyrgan and novasurol in the case of cardiac edema is readily understandable. It is more difficult, however, to account for the removal of accumulations of fluid resulting from portal obstruction and from depletion of the plasma proteins. Presumably the loss of water from the plasma resulting from the administration of these mercurial diuretics is sufficient to secondarily attract fluid from the tissue accumulations into the blood. With our present information, however, one can do little more than speculate in this regard. Further observations, both on the experimental animal and on patients with edema, are necessary before one can draw any definite conclusions.

\section{SUMMARY}

Rehberg's method of calculating the amount of filtration occurring in the glomeruli and the amount of reabsorption taking place in the tubules was used to compare the diuretic action of euphyllin and salyrgan in the dog.

During euphyllin diuresis the calculated amount of glomerular filtration is consistently increased while tubular reabsorption shows no constant change.

Salyrgan diuresis is characterized by a considerable decrease in the percentage of fluid reabsorbed in the tubules. The amount of filtration is seldom increased significantly.

The intravenous injection of normal saline solution characteristically increases the rate of glomerular filtration. The effect upon reabsorption varies with the amount of saline and the rate of injection.

The mechanisms by which mercurial and xanthine diuretics produce diuresis are discussed in the light of these findings and of the evidence available in the literature.

\section{BIBLIOGRAPHY}

1. Von Schroeder, W., Arch. f. exper. Path. u. Pharmakol., 1887, xxii, 39. Ueber die Wirkung des Coffeins als Diureticum.

2. Von Schroeder, W., Arch. f. exper. Path. u. Pharmakol., 1888, xxiv, 85. Ueber die diuretische Wirkung des Coffeins und der zu derselben Gruppe gehörenden Substanzen.

3. Loewi, O., Fletcher, W. M., and Henderson, V. E., Arch. f. exper. Path. u. Pharmakol., 1905, liii, 15. Untersuchungen zur Physiologie und Pharmakologie der Nierenfunction. III. Mitteilung: Über den Mechanismus der Coffein-diurese. 
4. Phillips, C. D. F., and Bradford, J. R., J. Physiol., 1887, viii, 117. On the Action of Certain Drugs on the Circulation and Secretion of the Kidney.

5. Gottlieb, R., and Magnus, R., Arch. f. exper. Path. u. Pharmakol., 1901, xlv, 223. Ueber Diurese. IV. Mitteilung: Ueber die Beziehungen der Nierencirculation zur Diurese.

6. Brings, L., and Molitor, H., Arch. f. exper. Path. u. Pharmakol., 1931, clix, 710. Über die Beziehungen zwischen onkometrisch verzeichneten Grössenänderungen der Niere und Diurese.

7. Cushny, A. R., The Secretion of the Urine. Longmans, Green \& Co. Ltd., London, 1926, 2nd ed., page 152.

8. Cushny, A. R., and Lambie, C. G., J. Physiol., 1921, lv, 276. The Action of Diuretics.

9. Schmidt, Erich, Arch. f. exper. Path. u. Pharmakol., 1924, ci, 66. Tierexperimentelle Untersuchungen über die Beeinflussung der Nierenfunktion durch intravenös einverleibtes Sublimat und Neosalvarsan unter besonderer Berücksichtigung des sogenannten Linserschen Gemisches (Neosalvarsan + Sublimat).

10. Ozaki, Masamichi, Arch. f. exper. Path. u. Pharmakol., 1927, cxxiii, 305. Pharmakologie der Nierengefässe.

11. Schmidt, Robert, Arch. f. exper. Path. u. Parmakol., 1922, xcv, 267. Über Diureseversuche an überlebenden Froschnieren.

12. Richards, A. N., and Plant, O. H., J. Pharmacol and Exper. Therap., 1915, vii, 485. Urine Formation by the Perfused Kidney: Preliminary Experiments on the Action of Caffeine.

13. Gremels, H., Arch. f. exper. Path. u. Pharmakol., 1928, cxxx, 61. Über die Wirkung einiger Diuretika am Starlingschen Herz-Lungen-Nierenpräparat.

14. Gremels, H., Klin. Wchnschr., 1928, vii, 1791. Zur Pharmakologie der Diurese.

15. Miwa, M., and Tamura, K., Mitt. d. Med. Fak. d. k. Univ. zu Tokyo, 1920, xxiii, 349. Beiträge zur Physiologie und Pharmakologie der Nierenfunktion. II. Über das Wesen der Coffeindiurese und den Einfluss der Salicylsäure auf die Niere.

16. Hartwich, Adolf, Arch. f. exper. Path. u. Parmakol., 1926, cxi, 206. Einfluss pharmakologisch wirksamer Substanzen auf die isolierte Froschniere. II. Mitteilung: Diuretika und andere Substanzen.

17. Dreyer, N. B., and Verney, E. B., J. Physiol., 1923, lvii, 451. The Relative Importance of the Factors Concerned in the Formation of the Urine.

18. Richards, A. N., and Schmidt, C. F., Am. J. Physiol., 1924, 1xxi, 178. A Description of the Glomerular Circulation in the Frogs Kidney and Observations Concerning the Action of Adrenalin and Various Other Substances upon It.

19. Richards, A. N., and Plant, O. H., Am. J. Physiol., 1922, lix, $184 . \quad$ Urine Formation in the Perfused Kidney. The Influence of Adrenalin on the Volume of the Perfused Kidney.

20. Richards, A. N., and Plant, O. H., Am. J. Physiol., 1922, lix, 191. The Action of Minute Doses of Adrenalin and Pituitrin on the Kidney.

21. Mendenhall, W. L., Taylor, E. M., and Richards, A. N., Am. J. Physiol., 1924, lxxi, 174. The Action of Minute Amounts of Barium Chloride upon the Kidney.

22. Verney, E. B., and Winton, F. R., J. Physiol., 1930, lxix, 153. The Action of Caffeine on the Isolated Kidney of the Dog.

23. Barcroft, J., and Straub, H., J. Physiol., 1910, xli, 145. The Secretion of Urine. 
24. Gremels, H., Arch. f. exper. Path. u. Pharmakol., 1929, cxl, 205. Über den Einfluss von Diureticis auf den Sauerstoffverbrauch am Starlingschen Nierenpräparat.

25. Wohlenberg, Willi, Arch. f. d. ges. Physiol., 1927, ccxviii, 448 . Über die Harnbildung in der Froschniere. XIII. Mitteilung: Untersuchungen über den Mechanismus der Purinkörperdiurese.

26. Barcroft, Joseph, Ergebn. d. Physiol., 1908, vii, 744. Zur Lehre vom Blutgaswechsel in den verschiedenen Organen. Die Nieren.

27. Hayman, J. M., Jr., and Schmidt, C. F., Am. J. Physiol., 1928, lxxxiii, 502. The Gaseous Metabolism of the Dog's Kidney.

28. Masuda, T., Biochem. Ztschr., 1926, clxxv, 8. Über dieWirkung diuretischer Gif te auf die cyanvergiftete Froschniere.

29. Sobierański, W., Arch.f. d. ges. Physiol., 1903, xcviii, 135. Weitere Beitrage zur Nierenfunction und Wirkungsweise der Diuretica. Ueber die Veränderung der Nierenepithelien unter dem Einfluss verschiedener Diuretica.

30. Tashiro, K., and Abe, H., Tohoku J. Exper. Med., 1922, iii, 142. The Dependence of the Nature of Caffeine Diuresis upon the Dose Used. I. Renal Oxygen Consumption and Blood Flow during Caffeine Diuresis.

31. Teploff, I., Ztschr. f. d. ges. exper. Med., 1929, lxix, 159. Die Purindiurese im Lichte der vitalen Carminfärbung.

32. Brühl, H., Biochem. Ztschr., 1929, ccxii, 291. Untersuchungen zur Membran- und Eiweiszwirkung des Coffeins.

33. Veil, W. H., and Spiro, P., München med. Wchnschr., 1918, 1xv, 1119. Ueber das Wesen der Theocinwirkung.

34. Ellinger, A., Heymann, P., and Klein, G., Arch. f. exper. Path. und Pharmakol., 1921, xci, 1. Die treibenden Kräfte für den Flüssigkeitsstrom im Organismus, Quellungsdruck der Eiweisskörper und Diurese. Zur Wirkungsweise des Coffeins als Diuretikum.

35. Fllinger, A., and Neuschlosz, S. M., Biochem. Ztschr., 1922, cxxvii, 241. Vergleichende Untersuchungen über Viscosität und Ultrafiltrationsgeschwindigkeit von Serum.

36. Faludi, Franz, Ztschr. f. d. ges. exper. Med., 1928, 1xii, 242. Über die Coffeindiurese.

37. Meyer, Paul, Ztschr. f. klin. Med., 1931, cxvi, 687. Untersuchungen über den kolloidosmotischen Druck des Blutes. III. Die Euphyllindiurese.

38. Curtis, G. M., Biochem. Ztschr., 1925, clxiii, 109. Beitrage zur Physiologie der Drüsen. Die Wirkungsweise der spezifischen Diuretica nebst Beiträgen zur Lehre vonder Harnabsonderung.

39. Curtis, G. M., Biochem. Ztschr., 1927, clxxxvi, 95. Fortgesetzte Untersuchungen über die Wirkungsweise der spezifischen Diuretica. Die Blockierung der normalen Reaktion durch die intraperitoneale Injektion von destilliertem Wasser.

40. Curtis, G. M., and Shambaugh, N. F., Biochem. Ztschr., 1927, clxxxvi, 112. Fortgesetzte Untersuchungen über die Wirkungsweise der spezifischen Diuretica. Die Blockierung der normalen Reaktion bei Kaninchen mit entnervten Nieren.

41. Curtis, G. M., Klin. Wchnschr., 1925, iv, 824. Die Wirkungsweise der spezifischen Diuretica.

42. Hartwich, Adolf, Biochem. Ztschr., 1926, clxvii, 329, Über die Beziehungen des Blutkochsalzspiegels zur Diurese.

43. Riesen, Werner, Biochem. Ztschr., 1930, ccxxvi, 441. Der Elektrolytaustausch zwischen Gewebe und Blut unter dem Einflusse der spezifischen Diuretica, ein Beitrag zur Lehre von der Diurese. 
44. Nakao, H., Biochem. Ztschr., 1926, clxxiii, 41. Vergleich der Wirkungsweise des spezifischen Diuretika bei normalen und dyspnoischen Tieren.

45. Nakao, H., Biochem. Ztschr., 1926, clxxviii, 342. Fortgesetzte Untersuchungen zur Lehre von der Harnabsonderung. Die Wirkung der spezifischen Diuretica unter dem Einflusse des vegetativen Nervensystems.

46. Raulston, B. O., Biochem. Ztschr., 1927, clxxxiv, 31. Fortgesetzte Untersuchungen zur Lehre von der Harnabsonderung. Die Wirkungen der spezifischen Diuretica im allergischen Zustand.

47. Büchler, H. W., Biochem. Ztschr., 1931, ccxxxiv, 441. Fortgesetzte Untersuchungen über die Wirkungsweise der Diuretica.

48. Molitor, H., and Pick, E. P., Biochem. Ztschr., 1927, clxxxvi, 130. Über zentrale Regulation des Wasserwechsels. IV. Die Aufhebung der diuretischen Coffein- und Theobrominwirkung durch Zwischenhirnnarkose.

49. Saxl, P., and Heilig, R., Wien. klin. Wchnschr., 1920, xxxiii, $943 . \quad$ Ueber die diuretische Wirkung von Novasurol- und anderen Quecksilberinjektionen.

50. Crawford, J. H., and McIntosh, J. F., J. Clin. Invest., 1925, i, 333, Observations on the Use of Novasurol in Edema due to Heart Failure.

51. Keith, N. M., and Whelan, M., J. Clin. Invest., 1926, iii, 149. A Study of the Action of Ammonium Chlorid and Organic Mercury Compounds.

52. Melville, K. I., and Stehle, R. L., J. Pharmacol. and exper. Therap., 1928, xxxiv, 209. Mercury Diuresis.

53. Möller, Knud, O., Arch. f. exper. Path. und Pharmakol., 1930, cxlviii, 56. Experimentelle Untersuchungen über die Pharmakologie des Salyrgans. I. Mitteilung. Untersuchungen über die Salyrgandiurese bei Kaninchen.

54. Nonnenbruch, W., Munchen med. Wchnschr., 1921, lxviii, 1282. Ueber die Wirkung des Novasurols auf Blut und Diurese.

55. Saxl, P., and Heilig, R., Ztschr. f. d. ges. exper. Med., 1923, xxxviii, 94. Über die Novasuroldiurese.

56. Noguchi, Inosuke, Arch. f. exper. Path. u. Pharmakol., 1926, cxi, 295. Experimentelle Beiträge zur Kenntnis der Novasurolwirkung.

57. Bohn, Hans, Ztschr. f. d. ges. exper. Med., 1923, xxxi, 303. Experimentelle Studien über die diuretische Wirkung des Novasurols.

58. Bohn, Hans, Deutsches Arch. f. klin. Med., 1923, cxliii, 225. Fortgesetzte Studien über Novasurol, seine Wirkung bei verschiedenen Lebensaltern und bei Diabetikern, sowie sein etwaiger Einfluss auf Ionenverschiebungen im Organismus.

59. Serby, A. M., Arch. Int. Med., 1926, xxxviii, 374. The Pharmacology and Therapeutics of Novasurol.

60. Mühling, A., Munchen med. Wchnschr., 1921, lxviii, 1447. Studie über die diuretische Wirkungsweise von Quecksilber. Ausgeführt mit dem organischen Quecksilberpräparat Novasurol.

61. Bleyer, L., Klin. Wchnschr., 1922, i, 1940. Erfahrungen über die Novasuroldiurese.

62. Fehér, Stephan, Wien. klin. Wchnschr., 1929, xlii, 964. Salyrgandiurese und zirkulierende Blutmenge.

63. Tezner, Otto, Med. Klin., 1923, xix, 788. Zum Mechanismus der Novasurolwirkung.

64. Recht, Georg, Wien. klin. Wchnschr., 1926, xxxix, 1046. Zur gewebsdiuretischen Wirkung des Salyrgans.

65. Brunn, F., Munchen med. Wchnschr., 1921, lxviii, 1554. Zur Wirkung des Novasurols als Diuretikum. 
66. Meyer, Paul, Ztschr. f. klin. Med., 1931, cxvi, 174. Untersuchungen über den kolloidosmotischen Druck des Bluts. II. Die Salyrgandiurese.

67. Fodor, Emmerich, Med. Klin., 1923, xix, 684. Über das Indikationsgebiet des Novasurols als Diuretikum.

68. Govaerts, Paul, Compt. rend. Soc. de biol., 1928, xcix, 647. Origine Rénale ou Tissulaire de la Diurèse par un Composé mercuriel organique.

69. Schloss, Anneleise, Arch. f. exper. Path. u. Pharmakol., 1930, clii, 27. Salyrgandiurese und Nierendurchblutung.

70. Kulcke, E., Klin. Wchnschr., 1922, i, 622. Novasurol als Diureticum.

71. Rehberg, P. B., Biochem. J., 1926, xx, 447. Studies on Kidney Function. I. The Rate of Filtration and Reabsorption in the Human Kidney.

72. Chrometzka, F., and Unger, K., Ztschr. f. d. ges. exper. Med., 1931, $1 \times x x, 261$. Untersuchungen über die Grösse des Glomerulusfiltrats unter dem Einfluss von Diureticis und Hormonen.

73. Folin, Otto, J. Biol. Chem., 1914, xvii, 475. On the Determination of Creatinine and Creatine in Blood, Milk and Tissue.

74. Bieter, Raymond, N., J. Pharmacol. and Exper. Therap., 1931, xliii, 399. The Action of some Diuretics upon the Aglomerular Kidney.

75. Fremont-Smith, F., Fremont-Smith, M., Dailey, M. E., Solomon, P., Stetten, De W., Jr., and Carroll, M. P., J. Clin. Invest., 1930, ix, 7. Studies in Edema. I. The Mechanism of Water Diuresis in Man.

76. Ekehorn, G., Acta med. Scandinav., Supp., 1931, xxxvi, 1-717, On the Principals of Renal Function. 